Review de Debut

\title{
供与・逆供与によるボリルアニオン・ ボリレンの安定化とその反応性
}

重田 雅之

\section{Stabilization of Boryl Anion and Borylene via Donation and Back Donation and Focusing of Their Reactivities}

Masayuki Shigeta

Low valent boron derivatives are attractive synthetic targets, because it has been difficult to prepare compared to other $p$-block element derivatives. In this short review, recent progresses on the preparation strategies based on the donation and back donation are described.

ボリルアニオンは, 13 族であるゆえに空軌道をもつ ことから，電荷こそ異なるがカルベンと同じ電子状態を とる(図 1)。そのため, 第 2 周期の他のアニオン種と比 較すると極端に不安定な化学種であり, これまでに単 離・利用に向けた様々な研究が報告されてきた。この化 学種を安定化させる方法は, 遷移金属とホウ素-金属結 合形成によるもの ${ }^{1)}$, 供与と逆供与が可能な「配位子」を 用いるものが代表的である。本稿では，後者の安定化に ついて，2010年から活発に報告されている結果を中心 に紹介する。加えて, 非常に安定性の低い, ボリレン (共有結合 1 つと非共有電子対を有する化学種)の単離に ついても紹介する。

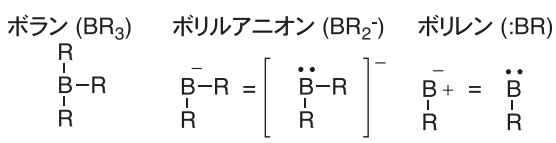

Fig. 1 Boran, boryl anion, and borylene.

1952 年に Auten, Kraus らにより，アルキル基置換の ハロボランの還元が報告された後 ${ }^{2}$, ボリルアニオンの 調製・利用を目指した研究が継続的に進められてきた。 そのなかで, 1994 年, 今本らは, ホスフィンに配位さ せることによりボリルアニオンを安定化させ，ホウ素原 子上で求電子置換反応を実現できることを報告した。す なわち, ホスフィンーボラン錯体 1 の THF 溶液に, $-78{ }^{\circ} \mathrm{C}$ でリチウムビス-tert-ブチルビフェニリド （LDBB）を作用させた後に，様々な求電子剂を作用させ ることで，対応する付加体をいずれの場合も高収率で得 られることを見出している $(\text { スキーム 1 })^{3)}$ 。

この今本らによる報告は, 供与能と逆供与能を有する 化合物をホウ素原子に連結させることにより，その原子 上の空軌道と非共有電子対を一挙に安定化させること で，ボリルアニオンを安定化できるという指標を示すも

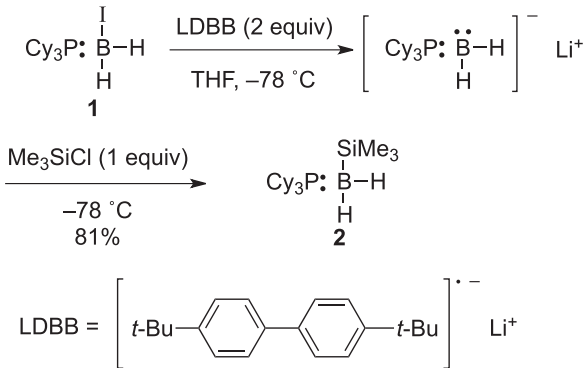

Scheme 1 Nucleophilic substitution by phosphine-boran complex. ${ }^{4}$

のであった。

その後, $N$-ヘテロ環カルベン $(\mathrm{NHC})$ が遷移金属のこ れまで隠れていた性質を露にするとして注目されて， 様々な錯体の合成が報告されるとともに，ボリルアニオ ンの安定化にも効果的に機能するとして利用されてき た。その先駆的な報告として，2010 年, Braunschweig らは, ペンタフェニルボロール誘導体 3 を $\mathrm{KC}_{8}$ で還元 することにより，ボリルアニオンを発生させて，その結 晶を単離することに成功している $(\text { スキーム 2 })^{5)}$ 。なお, ホウ素原子上の非共有電子対はカルベン配位子への逆供 与による安定化に加え, ボロールの芳香族安定化も寄与 していると推測される。

Braunschweig らは, ボリルアニオンの単離報告に続

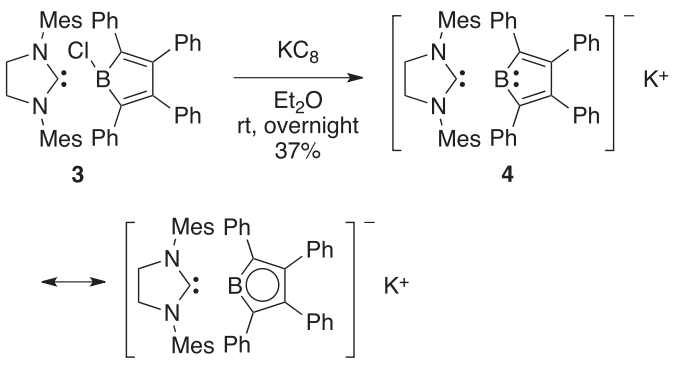

Scheme 2 Isolation of NHC-boryl anion complex. 
き，N-ヘテロ環カルベンによる安定化の方法をボリレ ンに拡張する検討を報告した。すなわち，2011 年に， イミダゾール-2-イリデンージクロロボラン錯体 5 を THF 中でナトリウムナフタレニドを作用させることに より，ナフタレンとの付加環化体であるボリラン 6 を収 率 $88 \%$ で得ている $(\text { スキーム } 3)^{6)}$ 。こつ結果は, ボリレ ンの発生を示唆するものであると Braunschweig らは述 ベている。一方で, ラジカル機構により反応が進行した という可能性もCurranらにより提唱されて扔り ${ }^{7)}$, 今 も活発に議論が行われている。

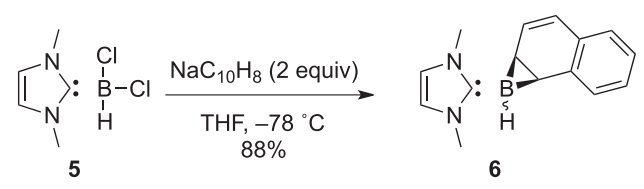

Scheme 3 Preparation of a borirane from NHC-borane complex.

Bertrand, 金城らは, Braunschweig らのボリレンに 関する報告と同時期に環状アルキルアミノカルベン (CAAC) を 2 分子用いて安定化させることにより, ボリ レンを単離することに成功している。すなわち, 環状ア ルキルアミノカルベンーボラン錯体 7 にトルエン中で $\mathrm{KC}_{8}$ を作用させることにより, 収率 $33 \%$ でボリレン 8 を得ている $(\text { スキーム 4 })^{8)}$ 。この際, 錯体 7 に 1 モル量 の環状アルキルアミノカルベンを添加して還元処理した 場合には収率が低下したことから(8\%), このボリレン 発生のメカニズムの詳細にも興味がもたれる。

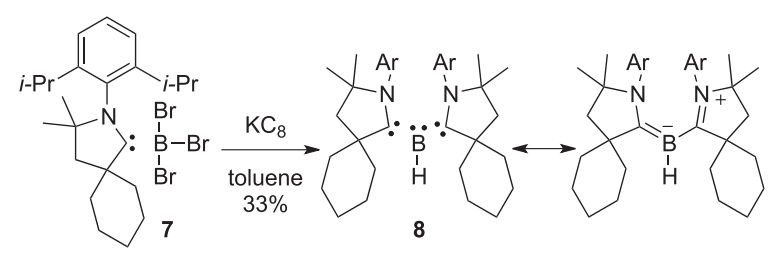

Scheme 4 Preparation of bisCAAC-borylene complex.

こうして合成されたボリレン 8 は, 室温においても単 離できるほど安定であり，1 当量の酸を添加した酸性条 件下に扔いてもこの構造を損なうことなく，さらにホウ 素原子がプロトン化された化合物が収率 89\% で得られ る(スキーム5)。

以上, 本稿ではホウ素の不安定化学種を供与・逆供与

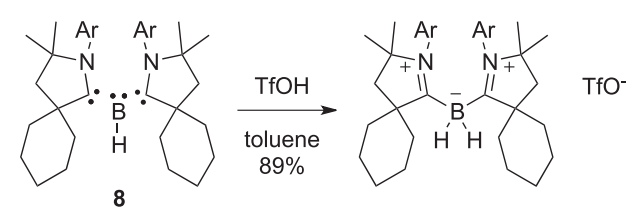

Scheme 5 Protonation of bisCAAC-borylene complex.
により安定化させることで合成に利用したり,さらには 単離も可能となってきた現状を紹介した。この戦略や遷 移金属とホウ素の結合形成とは別の方法も, 山下, 野崎 らにより報告されている $(\text { スキーム } 6)^{9)}$ 。この化学種は, 隣接する両窒素原子からホウ素原子への電子の非局在化 により，ホウ素原子上の空軌道に電子が充填されたこと で, ボリルアニオンの安定化しているものと推測され る。こういった戦略に基づくボリルアニオンの単離・利 用法については, すでに本誌に総説がまとめられてい $3^{10)}$ 。

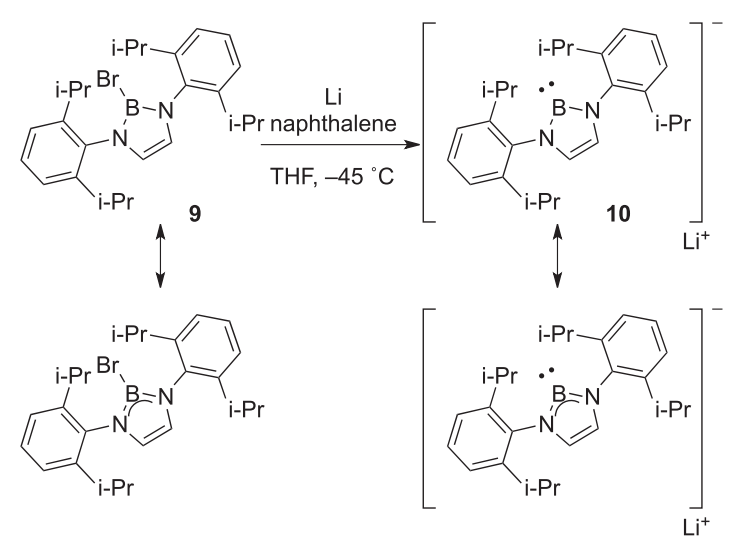

Scheme 6 Isolation of boryl anion via an isoelectronic analog of stable $N$-heterocyclic carbene.

文 献

1) H. Braunschweig, R. D. Dewhurst, A. Schneider, Chem. Rev., 110, 3924 (2010)

2) R. W. Auten, C. A. Kraus, J. Am. Chem. Soc., 74, 3398(1952)

3) T. Imamoto, T. Hikosaka, J. Org. Chem., 59, 6753(1994)

4）本稿ではホウ素原子の電子状態を明解に表現するため配位結合 とアニオン種をルイス構造式で表記し，また原著に記されてい ない共鳴構造を一部併記した。

5) H. Braunschweig, C. Chiu, K. Radacki, T. Kupfer, Angew. Chem. Int. Ed., 49, 2041 (2010)

6) P. Bissinger, H. Braunschweig, K. Kraft, T. Kupfer, Angew. Chem. Int. Ed., 50, 4704 (2011)

7) D. P. Curran, A. Boussonnière, S. J. Geib, E. Lacôte, Angew. Chem. Int. Ed., 51, $1602(2012)$

8) R. Kinjo, B. Donnadieu, M. A. Celik, G. Frenking, G. Bertrand, Science, 333, 610(2011)

9) Y. Segawa, M. Yamashita, K. Nozaki, Science, 314, 113 (2006)

10) M. Yamashita, K. Nozaki, J. Synth. Org. Chem., Jpn., 68, 359 (2010)

(2012 年 4 月 7 日受理)

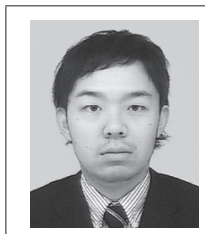

重田雅之 東京工業大学大学院理工学研究科有 機・高分子物質専攻 特任助教, 戦略的イノベー ション創出推進プログラム (JST) 博士 (理学) 〔所属研究室教授〕渡辺順次, 小西玄一〔経歴〕 2005 年東京工業大学理学部化学科卒業, 2010 年 東京工業大学大学院理工学研究科博士課程単位取 得退学 (鈴木啓介教授), 同年 10 月より現職, 2011 年博士（理 学)。〔研究テーマ〕有機合成, 光有機化学。〔連絡先〕 e-mail: mshigeta@polymer.titech.ac.jp 